\title{
Analytical investigations to estimate phosphorus re-dissolution rates in trace levels of selected topsoils and river sediments
}

\author{
STEFFEN HELLMANN ${ }^{1,2}$, GÜNTER KIESSLING ${ }^{2}$, \\ MATTHIAS LEITERER ${ }^{2}$, THORSTEN SCHÄFER ${ }^{1}$, MARCUS \\ SCHINDEWOLF $^{2}$ AND WOLF VON TÜMPLING ${ }^{3,4}$ \\ ${ }^{1}$ Friedrich Schiller University Jena \\ ${ }^{2}$ Thuringian State Office for Agriculture and Rural Areas - \\ TLLLR \\ ${ }^{3}$ Helmholtz Centre for Environmental Research - UFZ \\ ${ }^{4}$ Friedrich-Schiller-Universität Jena \\ Presenting Author: steffen.hellmann@uni-jena.de
}

Anthropogenic phosphorus (P) input from different fertilised agricultural topsoils into surface water and re-dissolution from sediments play a vital role in eutrophication. This study aimed to (i) analyse the $\mathrm{P}$ input and re-dissolution processes into streams/rivers and (ii) to study the effectiveness of the riparian strip in reducing $\mathrm{P}$ emissions from diffuse sources. Three laboratory experiments were designed to analyse $\mathrm{P}$ re-dissolution and leaching behaviour from topsoils and sediments and further extrapolated to reality based on the $\mathrm{P}$ main input path into surface waters, which is erosion [1].

In all three experiments, the first extraction after drying and sieving had significantly higher total $\mathrm{P}$ concentrations compared to inorganic phosphate, which was attributed to organic P. It was found, that the $\mathrm{P}$ re-dissolution rate was strongly related to the $\mathrm{O}_{2}$ concentration, $\mathrm{E}_{\mathrm{h}}, \mathrm{T}, \mathrm{pH}$ and ionic strength. It was shown that the $\mathrm{P}$ re-dissolution rate decreased with increasing dissolved $\mathrm{Ca}^{2+}$, $\mathrm{Fe}^{2+}$ and $\mathrm{Mn}^{2+}$ present.

The results indicated that the main $\mathrm{P}$ source into surface waters was leaching from sediment interstitial sites (57.5\%) received due to percolation while the $\mathrm{P}$ re-dissolution via diffusion (13\%), due to two heavy rain events $(17 \%)$ and leaching processes through soil interstitial sites $(12.5 \%)$ only played a minor role. The "Bund/Länderarbeitsgemeinschaft Wasser (LAWA)" orientation value causing eutrophication for total $\mathrm{P}\left(0.10 \mathrm{mg} \mathrm{L}^{-1}\right)$ [2] was exceeded in all sandy soils $(0.17-$ $\left.0.85 \mathrm{mg} \mathrm{L}^{-1}\right)$, only slightly in the clayey soils $\left(\leq 0.11 \mathrm{mg} \mathrm{L}^{-1}\right)$ and not in both sediments $\left(\leq 0.08 \mathrm{mg} \mathrm{L}^{-1}\right)$. P-Fertilisation led to higher extracted $\mathrm{P}$ concentrations from soil by deionised/synthetic water than unfertilised soils. However, local differences such as a steeper slope, different soil compositions (sand, clay content), as well as poorer buffering due to lower lime content were the decisive reasons for a higher risk of eutrophication. The effectiveness of the riparian strip at the sites investigated is discussed as well.

References

[1] Tetzlaff, Kreins, Kuhr, Kunkel, Wendland (2017), IBG 3 Agrosphäre, 153-154.

[2] Bund/Länderarbeitsgemeinschaft Wasser (LAWA) (2015), RaKon Part B Workpaper, 13-14. 